\title{
Organic soybean production in Switzerland ${ }^{\text {is }}$
}

\author{
Matthias Klaiss ${ }^{1, *}$, Nathaniel Schmid ${ }^{1}$, Claude-Alain Betrix ${ }^{2}$, Alice Baux ${ }^{2}$, Raphaël Charles ${ }^{1}$ and \\ Monika M. Messmer ${ }^{1}$ \\ ${ }^{1}$ Research Institute of Organic Agriculture FiBL Switzerland, Frick, Switzerland \\ 2 Agroscope, Nyon, Switzerland
}

Received 11 June 2020 - Accepted 23 October 2020

\begin{abstract}
Organic Soybean cultivation experiences an upscale at the moment in Switzerland. As in the rest of Europe, Switzerland is still heavily dependent on protein imports. After years of stakeholders efforts of the development of a value chain for organic soybeans for human nutrition, various attempts to develop the soybean cultivation for feed proved to be fruitful despite the fact that Swiss price level is beyond competition for world market prices. The organic farmers themselves decided to become, at least partially, more independent from overseas soybean imports by opting for organic soybeans of European origin since 2019. Furthermore, Bio Suisse decided that from 2022 on, all ruminants under Bio Suisse certification must be fed with feed of Swiss origin, concentrates are limited to $5 \%$ of the ration. Since many years numerous projects are carried out to increase the domestic protein production by developing suitable production systems for peas, faba beans, lupines and soybeans with stakholders along the value chain. Since more than 30 years, Swiss breeders successfully develop 00 to 000 soybean varieties with a focus on human nutrition, organic soybean cultivation and the respective value chains from breeding to endproduct is developing strongly. This article will shed light on particular aspects and drivers, specific measures, relevant projects and cultivation techniques of organic soybean production in Switzerland in the past years and will give an outlook on the future of organic soybeans.
\end{abstract}

Keywords: organic / soybean / Switzerland / domestic protein production

Résumé - Production de soja biologique en Suisse. La culture biologique du soja connaît actuellement un essor en Suisse. Comme dans le reste de l'Europe, la Suisse demeure encore fortement dépendante des importations de protéines. Après des années d'efforts des parties prenantes pour développer une chaîne de valeur pour le soja biologique destiné à l'alimentation humaine, diverses tentatives de développement de la culture du soja pour l'alimentation animale se sont avérées fructueuses malgré un niveau de prix suisse dépassant ceux du marché mondial. Les agriculteurs biologiques eux-mêmes ont décidé de devenir, au moins partiellement, plus indépendants des importations de soja d'outre-mer en optant pour des fèves de soja biologiques d'origine européenne depuis 2019. En outre, Bio Suisse a décidé qu'à partir de 2022, tous les ruminants sous certification Bio Suisse devront être nourris avec des aliments d'origine suisse, les concentrés étant limités à $5 \%$ de la ration. Depuis de nombreuses années, de nombreux projets sont menés pour augmenter la production nationale de protéines en développant des systèmes de production adaptés pour les pois, les fèves, les lupins et le soja avec des partenaires tout au long de la chaîne de valeur. Depuis plus de 30 ans, les sélectionneurs suisses développent avec succès des variétés de soja 00 à 000 en mettant l'accent sur l'alimentation humaine, et la culture biologique du soja et leurs chaînes de valeur respectives, de la sélection au produit final, se développent fortement. Le présent article met en lumière les aspects et les moteurs particuliers, les mesures spécifiques, les projets pertinents et les techniques de culture de la production de soja biologique en Suisse au cours des dernières années et offre un aperçu de l'avenir du soja biologique.

Mots clés : biologique / soja / Suisse / production nationale de protéines

\footnotetext{
is Contribution to the Topical Issue "Organic foods in the oil \& protein crop supply chain / Le «Bio » dans la filière oléoprotéagineuse".

*Correspondence: matthias.klaiss@fibl.org
} 


\section{Introduction}

This article will shed light on aspects of organic soybean production in Switzerland, specific measures and relevant projects of stakeholders to increase the domestic production of organic soybean for food and feed and drivers that increase the demand.

The source of information is unpublished data and a review of grey literature, extension material, informations from ongoing projects and stakeholders expert opinions and experiences. A large part of the technical literature consulted for this article is published in German and French language on the website bioactualites.ch as well as from the fact sheets made available to farmers and advisors involved in organic or conventional farming. They are also made available to a broad audience of farmers under the webpage organic-farmknowledge.org which is offered in 14 languages. The content of technical leaflets evolves with trials and experiences on projects carried out. Their analysis allows following the evolution of practices in organic agriculture. Their cross-referencing with literature from conventional agriculture helps to situate the specific issues of organic farming. An analogous crossreference with current scientific literature clarifies the evolution of the problems as well as persistent or new research needs.

\subsection{Overview of organic agriculture in Switzerland}

Switzerland has a total land area of $41285 \mathrm{~km}^{2} .9 .9 \%$ of this area is arable land. The total agricultural area diminishes steadily due to the spread of settlements (lowlands) and the range of forest (mountain areas) (www.bfs.admin.ch). By the end of 2018, Switzerland and Liechtenstein had approximately 45474 farms, 7217 of which were organic farms, which is $15.8 \%$. Approximately $93 \%$ of organic farmers are members of the Bio Suisse organic farmers association. $15.4 \%$ of the total land-use area is under organic certification (Bio Suisse 1, 2018). Since 2009, the organic area has grown approximately 3-7\% annually (FiBL Statistics, 2020)

According to Baur (2011), 80\% of the crude protein used as feed in conventional and organic agriculture in Switzerland is of domestic origin. However, there is a large disparity between the animal species, for ruminants, the proportion of domestic production was $90 \%$ or more, for pigs and poultry the portion of protein from domestic production in 2008 was only 36 and $27 \%$, respectively.

After years of rapid growth in the demand for domestic organic arable crops, the supply of many traditional organic arable crops like wheat, barley, oats, triticale and maize has stayed relatively stable. More precisely, it follows the growing trend of the organic market share, which is estimated to be $9.9 \%$. In 2018, on average, every person living in Switzerland spent CHF 360 on organic food (Bio Suisse 1,2018), which still leaves a broad scope for progress. However, new organic farmers are less inclined to produce the most accessible organic crops but rather increase the interest in new markets and crops.

Protein crops are under exceptionally high demand to reduce dependencies from imports. In that respect, the prospect for the development of Swiss soybean production is all the more pronounced as demand is high and exceeds production.

\subsection{Organic soybean production in Switzerland}

In 2014,1500 ha of soybean were cultivated in Switzerland (organic and conventional), with a total yield of 3882 tons. $2000 \mathrm{t}$ were used as feed. (www.sojanetzwerk.ch). Only a few pioneers produced organic soybean for on-farm feed and a few pioneering processors for human consumption. Production of soybean was unattractive due to the long vegetation period (125 to 150 days) and cheap imports mainly from overseas or China. In 2016 the Soybean Network Switzerland (www. sojanetz.ch) was founded by 19 organisations of soybean buyers, producer associations, manufacturers, retailers and WWF-Switzerland. All actors are committed to sustainably sourcing soybean for the Swiss market. According to the Sojanetzwerk Schweiz, 269000 t of non-GMO soybeans and soybean cake (organic and non-organic) were imported to Switzerland in 2018, more than $40 \%$ was produced in Europe, and the rest originated mainly from Brazil (www.sojanetzwerk. ch, 2020). Organic soybean was mostly imported from China to avoid GMO contamination.

Soybean is indeed one of the few legumes available and proves to be essential to ensure balanced rotations, mainly in plain land without cattle. Ideally positioned as a diversification crop, soybean is particularly interesting from an ecological point of view since it does not need any supplementary nitrogen nor fungal treatment.

Soybean is a valuable crop for organic production as the need for food and feed is quickly rising (Schori et al., 2003).

The organic soybean cultivation increased from 52 ha in 2010 to 306 ha in 2018, and further to 461 ha in 2019 (Willer and Lernoud 2019; FiBL Statistics, 2020) the organic soybean production area is expected to increase in 2020 by more than $60 \%$ (Oral Information, Bio Suisse 2020).

Due to a considerable difference of quality demands and the producer price, we distinguish organic soybeans value chain for human nutrition and soybeans for feed.

\section{Soybean breeding in Switzerland}

\subsection{Background}

Agroscope is the national agricultural research institute for Switzerland. In Changins (Switzerland), a non-GM soybean breeding program started in 1981, with the support of the company Nestlé for four years. Then, the Federal Office of Agriculture decided to support it. With the arrival of the first Swiss varieties in 1988, soybean crops were introduced in Switzerland.

\subsection{Breeding goals}

Soybean is native from northeast China (Manchuria). Therefore, considerable work regarding climatic adaptation has been carried out to adapt this crop to our particular conditions north of the Alps. The first breeding objectives focused on the development of cultivars with low-temperature requirements and highly tolerant to cool temperatures during blooming. These parameters are essential to obtain good yield stability in Switzerland. Secondly, with the aim to add extra value to Swiss varieties, the breeders have quickly focused on human food. Soybeans typically have a grassy taste, not highly 


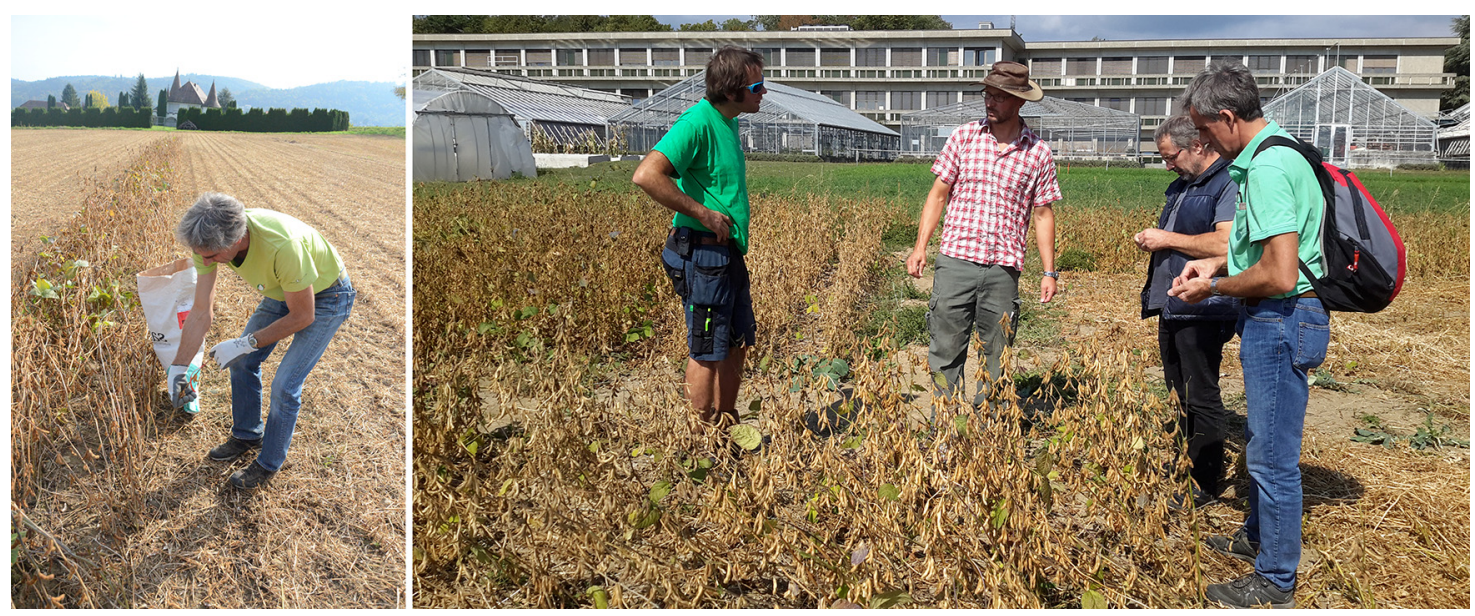

Fig. 1. A farmer in northwestern Switzerland (Aargau) selecting individual soybean plants within the heterogeneous CCP population on his organic farm (left). Farmers receiving initial training in selection of soybeans from breeder Claude-Alain Bétrix at Agroscope Changins in Nyon, Sept. 18 (right).

esteemed by Europeans. Significant work has been done to adapt the flavour of the bean. More recently, a soybean processing laboratory was developed to improve the technical processability of the Swiss varieties. The food industry is looking for high content and high qualities of proteins, allowing for important tofu yields with good firmness.

\subsection{Breeding method}

The breeding model adopted at Agropscope Changins for this self-pollinating species begins in the greenhouse with crossings parental plants which were cultivated in the field. Every year, 50-80 crosses are carried out, among which nearly a third of combinations of late $\mathrm{x}$ early type, to enlarge the bases of the genetic material. The obtained progenies are divided into two sub-populations on which mass selection is applied from F3 to F5 in two separate nurseries (Switzerland and Southern France). The two following years, pedigree selection allows keeping the most efficient lines at each location, ensuring a sufficient homogeneity needed to start performance testing in plots and maintenance selection. Then, a trial network is set up for three years to observe the diverse agronomical characteristics. During this time, quality tests are also taking place in parallel. This work ends with the selection of the best lines and future crossing parents. A network of official tests under conventional and organic conditions was recently established in 2019. A prescreening of about 15 advanced lines of different ripening groups and uses can be achieved. Numerous cultivars have been registered in the national catalogue and also in some neighbouring countries. The Swiss varieties are well known for their excellent yield stability, improved taste and suitability for tofu processing. The range of earliness consists mainly of early material (0000-00) and some late varieties (0-I).

\subsection{New breeding goal: weed competition and weed tolerance}

Recently, new projects have started with the goal of improving soybean tolerance and competitiveness against weeds in order to increase the performance of varieties in organic farming and reduce the use of herbicides in conventional agriculture. Weed tolerance can be defined by the ability of the crop to maintain high yield regardless of weed pressure, and by the ability of the soybean to compete with weeds. To overcome the problems of homogeneity of natural weed populations in the field, "Artificial Weeds" (AW) were used to mimic weed competition by simultaneous planting of soybean with other species. Multiple combinations were tested. In the end, a mixture of lentil, flax and buckwheat provided the best results. The competition had to be strong while still allowing the soybean to achieve sufficient yield. Different criteria, like canopy cover or leaflets shape, have been established and are currently being verified. After a thorough study of the different tolerance mechanisms, these indirect criteria should ensure good progress on traits in the future. The early generations in the nursery are already screened according to these new characteristics (Bétrix, C.-A., unpublished).

\subsection{Participatory organic breeding}

FiBL and Agroscope established a network for participatory selection with organic farmers in the southwest, northwest and northeast of Switzerland. An F3 Composite Cross Population (CCP) as pre-breeding material was provided by Agroscope using promising cultivars and accessions with desirable traits (20 different crosses were mixed). The participating farmers (see Figs. 1 and 2) received initial training. The aim was to select an adapted CCP that could be used by farmers as farm-saved seeds (they have the right to multiply seeds for their farm, but are not allowed to pass them on or sell them) and by breeders as a resource for breeding material. Furthermore, CCPs are a potential tool for climate change resilient crop production, minimising the risk of yield failure through genetic diversity, as shown for other selfpollinating crops like wheat (Döring et al., 2015).

\section{Variety evaluation and registration}

\subsection{Background}

For the evaluation of new varieties for the national catalogue and the list of varieties recommended for different 


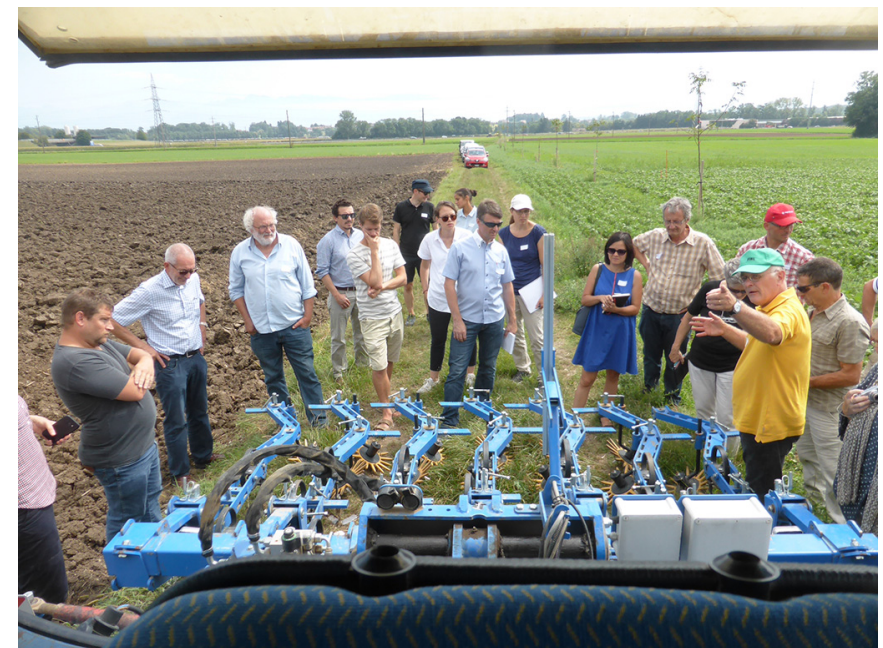

Fig. 2. Field visit in southwestern Switzerland with breeders, farmers, retailers, processors, and scientists to exchange and learn about challenges and chances along the organic soybean value chain in Switzerland. FiBL advisor Maurice Clerc explains mechanical weed management in organic soybeans.

farming systems, a network of 4-5 sites have been set up to test yearly a set of different varieties derived from national and international breeding. Besides grain yield and earliness, traits like seed composition (protein, antinutritional factors for feed or food), cold tolerance, drought tolerance and weed competition are of interest for both conventional and organic agriculture. The recommended list of soybean varieties published every year (Schwaerzel et al., 2019) gives the main characteristic of the varieties available for cultivation in Switzerland.

\subsection{Variety evaluation under organic conditions}

For over 30 years, Switzerland has cultivated conventional soybean varieties with improved cold tolerance to be adapted to Swiss cultivation conditions. With the very little occurrence of diseases in our region, the primary constraint in organic soybean cultivation is weed control. It is the crucial point for successful organic soybean production due to slow initial crop development and comparatively little competitiveness of soybean varieties at the beginning and end of the vegetation period.

FiBL and Agroscope together started on-farm variety tests in a replicated plot design under certified organic conditions, with the first organic trial site from 2013 on (Hiltbrunner $e t$ al., 2017), and a first network of three sites from 2016-2018 in the project Bio Speisesoja Schweiz, financed by retailer Coop and Bio Suisse. Breeding lines and varieties were assessed in addition to general observations for canopy cover and fast initial development as an indicator for competitiveness against weeds, to identify varieties and breeding lines that facilitate weed control.

Since 2018, the organic soybean variety test network (15 breeding lines and varieties) merged with the conventional low-input network for the national variety catalogue into a mixed network of four conventional and three organic sites across Switzerland with 25 cultivars. In addition, the grains of all cultivars are processed and transformed into tofu using a standardised laboratory method (www.agroscope.admin.ch).

\section{Main drivers of Swiss organic soybean production}

Being a comparatively new crop for organic agriculture in Switzerland, only a few pioneers had successfully produced organic soybean. Knowhow for organic cultivation was not common, especially for the highest quality demands of processing for human consumption. The fluctuation of producers was high, those farmers whose crop failed turned to other crops, a stable pool of organic soybean producers did not exist and other crops were more profitable with less risk for farmers. The price was not attractive then, too. However, as a first step, the retailer could be convinced that, in order to setup and maintain a stable producer pool and to develop organic food soy, the price must be more appealing to farmers.

\subsection{Agricultural extension}

All of the extension material is provided by FiBL on the FiBL Shop (https://shop.fibl.org/) and on the major knowledge platform for Swiss organic farmers Bioaktuell.ch. Information is accessible at no cost and in several lanuages (German, French, partly in Italian), also extension material from other sources outside Switzerland are linked on bioaktuell.ch. Furthermore, FiBL provides more than 350 extension videos on YouTube https://www.youtube.com/user/FiBLFilm, also videos that concern the production of grain legumes. FiBL is closely cooperating with cantonal extension services.

Bio Suisse finances projects to develop organic arable cropping with a fund created from a contribution per hectar organic arable land, the Knospe Ackerbau Projekte. A group of Bio Suisse experts, cantonal advisors and farmers prioritizes the needs of farmers for applied practical on-farm projects to develop arable crops and evaluates the projects applying for funding accordingly. With this fund, small projects like unreplicated variety strip trials in farmers' fields, farmer field visits and knowledge exchange could be financed and could contribute to larger national or EU wide projects.

Lists with recommended varieties for organic agriculture are an integral tool to facilitate organic production. FiBL and Bio Suisse provide lists for several crops with most recommendations based on trials (For details see Chapter 5.4)

Extension and networking events with demo trials like the biannual Bioackerbautag (https://bioackerbautag.ch/) are also a very important extension and development platform in Switzerland. They are organized and financed by a multistakholder team of all relevant organizations. Furthermore European projects described in Section 4.2 facilitate the development of organic soybeans in Switzerland.

\subsection{Projects aiming to develop the sector}

Since the beginning of 2010, multi-stakeholder projects with actors from soybean production chain from breeders, actors of applied agronomic research, seed production, 
extension, collection centres, trade, processing and retail were carried out. These projects aim to develop and foster a certified organic soybean value chain, first for food, then for feed. To upscale and optimise production, the project Bio Speisesoja Schweiz (www.fibl.org 1) was carried out from 2016-2018, cofinanced by COOP Sustainability Fund and Bio Suisse. The objective was to find solutions for the difficulties in organic soybean cultivation as well as in the production chain in cooperation with all involved stakeholders: breeders, seed producers, farmer organisations, a milling company (drying and cleaning), tofu processors, researchers, agricultural extension and COOP as a major retailer. The project served to link and coordinate actors in the Swiss organic soybean supply chain. They exchanged and shared questions and ideas to create stable framework conditions of production for all Swiss organic soybean actors. This framework addresses research gaps like breeding for weed competition, mechanical weed control, variety specific organoleptic tests, as well as market and price development.

Various aspects of cultivation methods were optimised in on-farm experiments in order to improve yield stability at lower costs. A specialist counselling and training for farmers was set up, newsletter and practical advisory material was provided online and via print media, and videos on the FiBL YouTube channel. Common events like field days or excursions were offered to link and encourage communication and exchange among actors up and down the value chain (Fig. 2).

Existing varieties and breeding lines were evaluated for their agronomic performances under organic conditions and technological quality (yield and firmness of tofu). They were further analysed for the processing steps in cooperation with partners from the industry and retailers (tofu production, milk, tasting and product trials). Processing trials and tasting events with tofu and soybean milk producers also took place.

Follow up projects focus on a multi-stakeholder approach and the continuation of breeding efforts for varieties suitable for local organic production, weed tolerance, suitability for feed and food purpose. Furthermore, participatory breeding schemes, training of farmers, promotion of soybean cultivation and development of training materials are maintained by the national project "Entwicklung von Selektionssystemen und partizipativer Züchtung auf Unkrautunterdrückung bzw. -toleranz für Schweizer Sojader Biozüchtung" (see www. fibl.org 2) cofinanced by the Federal Office for Agriculture (FOAG) and several European projects:

LegValue (www.legvalue.eu): To encourage an increase in the share of legumes in rotations in Europe, and to disseminate and share between countries all the information and institutional and private experiences, the LegValue project has facilitated a local assessment of value chain networks in each country and region. These exchanges have highlighted all the agronomic development work carried out as mentioned above, and allowed for the creation of a complete list of the challenges and opportunities prevailing in the commercial, technical (processing), geographical (suitability of regions for growing legumes and which), societal (diet patterns) and economic (interests of cooperatives and the food and fodder industry) sectors.

Legume translated (www.legumestranslated.eu) supports the production and use of grain legumes ("protein crops").
As a thematic network, it helps farmers benefit from relevant research, particularly research funded by the European Union. Legumes Translated addresses how we obtain and use protein, which is a fundamental factor in the resilience, performance and acceptance of our farming systems. Legumes Translated is part of the European Innovation Partnership for Agricultural Productivity and Sustainability (EIP Agri). The consortium comprises 18 partners in 9 countries with 15 local innovation groups (actor groups).

The overall goal of the project DiverIMPACTS (www. diverimpacts.net) - Diversification through Rotation, Intercropping, Multiple Cropping, Promoted with Actors and value-Chains towards Sustainability - is to achieve the full potential of cropping system diversification for improved productivity, delivery of ecosystem services and bolstering resource-efficient and sustainable value chains.

The scaling up of organic soybean in Switzerland mainly started with the development of food chains. Since beginning of the introduction of soybean in organic crop rotations, cultivation techniques and knowhow have improved considerably and Swiss cultivars adapted to organic farming could be identified. This enables farmers to gain confidence and equip themselves according to well-defined criteria required for food soybeans. This gain in technology, the reduced risk of yield fluctuations, and reasonable price for food market has attracted the interest of farmers to produce organic soybeans in Switzerland. These farmers are also interested now in soybean production for the feed supply chain, although prices are much lower.

\section{Market drivers}

\subsection{Organic soybeans for human nutrition}

The industry and large retailers have been committed to pay a higher price for the establishment of a minimum cultivation area of organic food-grade soybean derived from domestic production (Swissness: tofu produced in Switzerland from Swiss cultivars). The price negotiated between the processing industry/retailers allowed the company to secure domestic supply by offering a price to farmers that allows them to start growing food-grade organic soybeans, invest in adequate equipment and take certain risks related to the lack of production experience. This price was set assuming an increased risk of yield failure or insufficient quality of the harvest, fixed costs and the high variability of variable costs, mostly related to manual weed control leading to additional labour costs. The price of fodder soybean initially remained very low and did not convince the farmers as the gross income could not compete with other crops. COOP is one of the main retailers in Switzerland and has a close strategic cooperation with Bio Suisse resulting in a strategy to sell organic products mainly with the Bio Suisse Bud-Label. However, one of the key players in the development of Swiss organic soybean (and other crops) is, no doubt, Mühle Rytz, a family-owned company specialized on developing and buying organic arable crops and production of feed and raw material for the organic processors (www.muehlerytz.ch). As one of the suppliers for the processing companies of COOP, they could convince the retailers to produce organic tofu with organic soybean made in Switzerland from breeding to sales. To remove bottlenecks and 
to allow upscaling of the value chain, COOP Sustainability Fund funded the multi-stakeholder project Bio Speisesoja Schweiz project.

More and more companies use Swiss organic soybeans as a raw material for their products, as the Swissness label (www. ige.ch) appeals to consumers, allowing competition with the significantly cheaper imported products. Most of the Swiss organic food soybean is processed to tofu. There are marginal quantities of other $\mathrm{CH}$ organic soybean based products from various companies such as soyadrink, tempeh, flocks, even sojasauce etc. The demand is growing slow but steadily. Milk subsitutes are rather produced with oats now. To further boost the demand and to allow farmers to create more value on the farm, FiBL started to offer courses for on-farm processing of soybeans to tofu. (see www.bioaktuell.ch)

The average gross margin for organic food soybean in Switzerland, including the price support of Bio Suisse, is similar or considerably to the profit for bread wheat, depending on the ability of farmers to keep the cost for manual labour for weeding low. However, this is not true for soybean that enters the feed channel.

\subsection{Organic soybeans for feed}

In 2019 the delegates of Bio Suisse member organisations voted for a change in feed policy (Bio Suisse 3, 2015). Since 2020 ruminants on Bio Suisse farms must be fed with $90 \%$ domestic feed and from 2022 onwards, all feed must be of Swiss origin both as roughage and concentrated feed. Concentrates will be limited to a $5 \%$ share of the ration (Bio Suisse 2). The consequence is, that the need for domestic organic soybean, as the grain legume with the highest protein content, is growing rapidly and production needs to be upscaled quickly to satisfy the estimated demand of 2500$6000 \mathrm{t}$ (corresponding to $1000-2500 \mathrm{ha}$ ) at a price presently $36 \%$ lower than food-grade soybeans. Again, Mühle Rytz is a key player in the development of organic feed soybean, along with farmers association fenaco. Another consequence expected is that farmers reduce production of arable crops in favour of forage production for their animals.

\subsection{Food soybean quality specifications and contract farming}

A contract farming scheme was initiated by Mühle Rytz and Progana, an organic producer organization, for COOP tofu production in order to meet the quality criteria for soybean required by the industry and provide fair conditions for famers to facilitate the production. These contracts stipulate the quantity, the price and the minimum quality criteria to be met.

For soybean for the food chain contracts include varieties to be used, organic certification needed (Bio Suisse), communication for example about changes in soybean-area on the farm after signing the contract, planning, advise and communication of harvest, exclusion of soils to be grown on (no black peat soil due to massive weed pressure), removal of nightshade plants prior to harvest to avoid contamination with alkaloids, specifications and thresholds of pollution leading to downgrading of harvest to feed soybean if quality criteria are not met. Further quality criteria include minimum protein content, smell: clean, typical of the species, taste: clean, reminiscent of hazelnut, not rancid, and appearance and colour of the grains. However, the two companies buying soybean for food have different quality demands.

For feed grade soybeans, the basic quality demands specified by swissgranum are applied (Swissgranum, 2019). They include specifications on pollution and thresholds only.

\subsection{Price support as an instrument of Bio Suisse to develop crops}

Domestic organic production could not satisfy the demand for most organic arable crops in Switzerland. Hence, crops were imported. The price difference of imports with domestic organic products was skimmed off by Bio Suisse, and the money was put in a fund. With this fund, Bio Suisse could support producer prices of underdeveloped crops to make the production more interesting for farmers. Until 2019, for example, in addition to the market price for protein peas and faba beans, farmers got a bonus from Bio Suisse to support and develop legume production. In 2019, the support for peas and beans ended in favour of soybean for feed and lupines (CHF $350 / \mathrm{t}$ ). The producer price for feed soybean is CHF 1050/t plus CHF 350/t Bio Suisse contribution. The industry sets the cost of food grade soybeans in consultation with the various players, to support the development of the $100 \%$ Swissness sector at CHF 2200/t for goods meeting the quality criteria required by the industry and stipulated in the takeover contracts for the company buying the harvest. The producer price for food soybeans, however, is not supported with a bonus.

As more and more farms convert to organic, domestic production of many crops could satisfy the demand, there was no longer a need for imports. So now the fund which supported the development feed soybean and lupines is financed by producers of domestic feed wheat by accepting a deduction of $\mathrm{CHF} 10 / \mathrm{t}$ on the producer price. Other means of funding are under discussion.

\section{Agricultural practice of Swiss organic soybean production}

\subsection{Available practical guidelines}

\subsubsection{Position in the organic rotation}

To minimise weed pressure, soybeans should be grown not too long after the grass-clover $(20 \%$ of rotation compulsory in Bio Suisse organic label) and in any case not on plots on which there has been no temporary grassland for decades (e.g. under conversion).

As preventive measures for weed control, the choice of suitable fields, careful design of the crop rotation to minimise weed pressure and adapted management of the crop using suitable machines and techniques for weed control are crucial (Bernet et al., 2016).

Pre-crop effects of soybean are generally estimated to be lower than those for faba beans, lupine and peas. Soybean is very high in protein and absorbs a lot of nitrogen from the field. The residual nitrogen available for the next crop can be up to 30-50 kg (Richner and Sinaj, 2017); some publications 
propose values around 0 or even negative values (KTBL, 2015). Essential is a successful inoculation with Bradyrhizobia as the $\mathrm{N}$-fixing symbiotic bacteria are not native in Swiss soil.

The good soil cover during the season, the robust root system and the biomass left after harvest, which is quickly absorbed by the earthworms, generally leave a good soil structure. In practice, this favourable effect compensates to a large extent the small amount of nitrogen left over for the following cereal crop.

\subsubsection{Fertilization}

High amounts of nitrogen in the soil promotes weed growth and vegetative growth of soybeans and hence facilitates lodging. It has little or no effect on yield. Excess nitrogen can even prevent successful nodulation with nitrogen-fixing Bradyrhizobia. On the other hand, a supply of organic residue compost (which is very low in nitrogen), or moderate supplies of manure or manure compost is not a problem. Although not explicitly recommended, low starter fertilisation of liquid manure is sometimes used to help the initial growth of soybean in cold soils where symbiosis is generally delayed.

\subsubsection{Variety choice}

Organic seeds of several early varieties (ripening group 000 to 00 ) are available for organic agriculture in Switzerland. Most of these varieties were developed by the publicly funded Agroscope and seed production takes place in the country (Delley Seeds and Plants Ltd, www.dsp-delley.ch). Only seeds from few cultivars are imported. Varieties optimised for human nutrition (high protein content, taste, tofu yield) currently on the market are Proteix $(\mathrm{CH}, 00)$ and Aveline $(\mathrm{CH}, 000)$. In case of seed scarcity other varieties are also used (Gallec $(\mathrm{CH}$, 000)). For feed soybean, varieties optimised for high yield like Galice (00/000), Obélix (000), Aurelina (00) Merlin (000) are used (Dierauer and Klaiss, 2019). To facilitate variety choice for farmers, FiBL provides in cooperation with Bio Suisse lists of recommended varieties for almost all crops, most of them are based on results of cultivar trials conduced under organic conditions (www.bioactualitées.ch 2).

Results from variety trials for soybean varieties under organic and non-organic conditions are shown in Figure 3. This includes both released varieties and candidate varieties (still with numbers instead of names). Quality-oriented varieties for tofu production (e.g., Proteix, Aveline) need a high protein content which is usually linked to lower yield, whereas for feed production to total protein yield is of importance.

The food industry prefers varieties with a white hilum, to avoid the undesired colour of the end product, mostly in tofu and "milk". However, as Miersch (2017) states, the colour of the hilum does not at all influence the colour of the end product tofu, as it is removed with the okara during the soy-milk production. However, for the use of okara the colour is of importance.

\subsubsection{Organic seed}

As for all crops, organic soybean seed must be used according to national and European organic regulation.
Protein Yield and Maturity of Swiss Soybean Cultivars from Replicated Field Trials 2016-2019

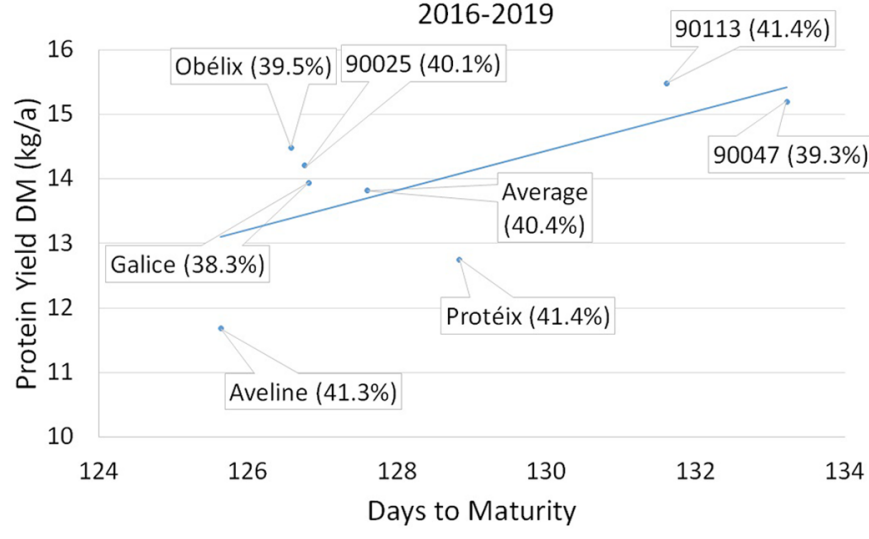

Fig. 3. Protein yield and maturity of Swiss soybean varieties from replicated field trials 2016-2019 carried out by FiBL and Agroscope under organic and non-organic conditions. Maturity groups: 90025 (000), 90047 (00), 90013 (00), Aveline 00/000, Galice (00/000), Obélix (000), Proteix (00). Protein content (\% dry matter DM) in parantheses behind variety names.

Usually, organic seed supply is sufficient, and no derogation for conventional seeds can be obtained from competent authorities. In rare cases, the offer of organic seed does not meet the demand and conventional untreated seeds can be used after the competent authorities grant a derogation. In this case, Bio Suisse skims of the price difference between organic and conventional seeds to equalise the cost for all organic farmers (incentive tax). This system is also applied to other crops with domestic seed production (wheat, other cereals, also potatoes, and even fruit trees). The money goes to a fund supporting projects which increase the availability of respective organic reproductive material. This system is anchored and defined in the Bio Suisse regulations (Bio Suisse 4, 2020).

\subsubsection{Inoculation}

With the soil bacteria Bradyrhizobium japonicum symbiotically colonising the plants roots, soybeans can fix atmospheric nitrogen $\left(\mathrm{N}_{2}\right)$. Because this bacterium is not native to European soils, soybean seeds must be inoculated with Bradyrhizobium strains just before sowing (Zimmer et al., 2016). Tested products must be used according to manufacturer's instruction, as insufficient nodulation will result in considerable yield loss and reduced protein content. In recent years, pre-inoculated seed has become more popular; however, we still recommend additional inoculation, as the shelflife of inoculation is not always sufficient and failure of inoculation is a financial risk. For the moment only peat based inoculants are on the market in Switzerland. In contrast to France, there is no restriction in the strains of Bradyrhizobia that can be applied.

\subsubsection{Sowing and seed quality requirements}

Most organic farmers in Switzerland buy certified seeds. Farm saved seed use of soybean is rather uncommon in Switzerland. The farmers' privilege (Landwirteprivileg) which is protected by law, however, would allow them to do so. 


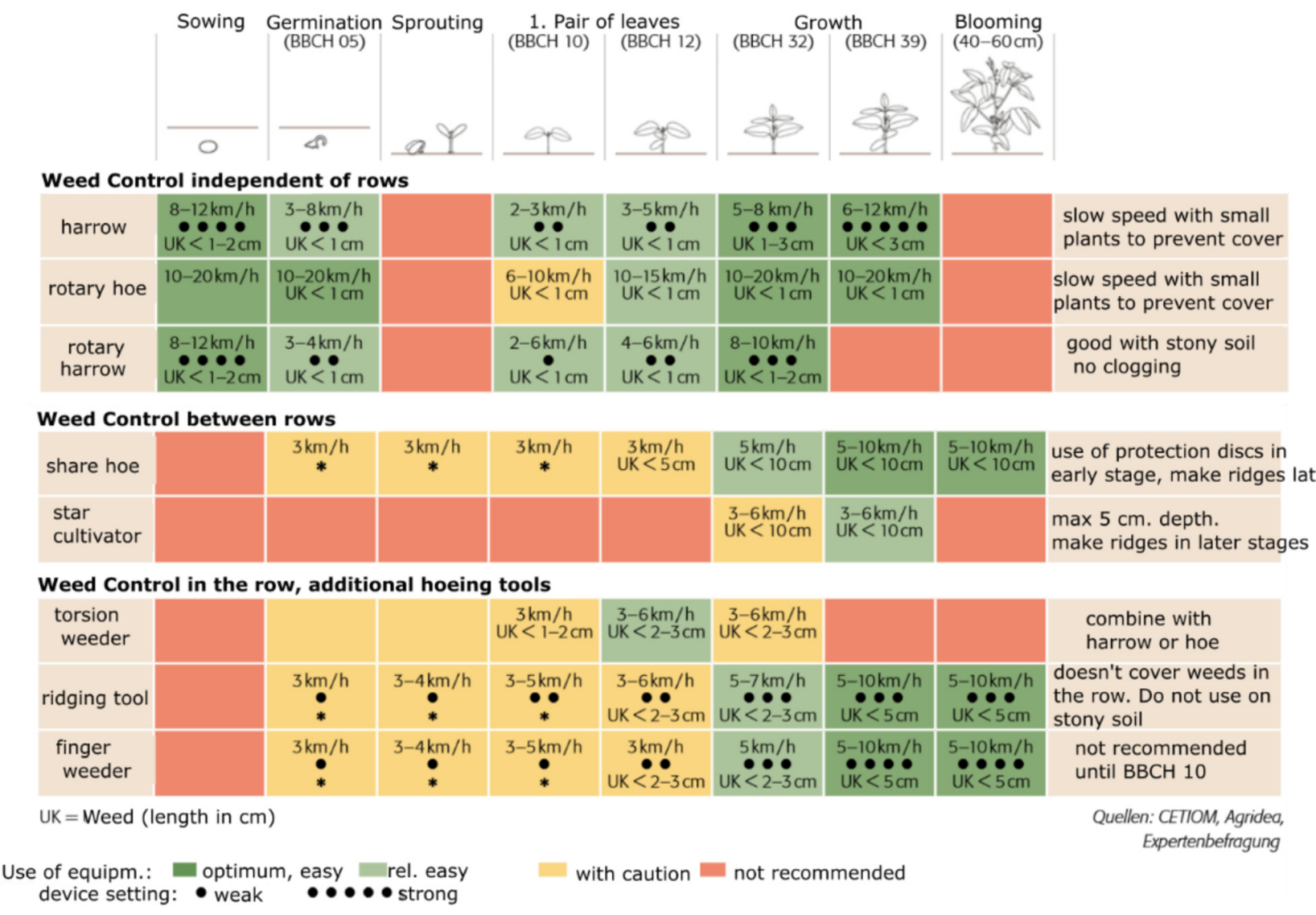

Fig. 4. Mechanical weeding in organic soybean at a glance. Source: Bernet et al. (2016).

In late April and early May, there may be late frosts and prolonged cold and wet periods. Soil temperature should be at or above $10^{\circ} \mathrm{C}$ to ensure the quick development of the soybean and enhance competitiveness with the weeds. As a rule of thumb, it is recommended to sow organic soybean between May 10th and May 20th. The date aims at flowering as early as the first half of July to avoid low temperatures $\left(<15^{\circ} \mathrm{C}\right)$ which lead to flower abortion (Bernet et al., 2016).

On south-facing plots with a mild climate (e.g. near lakes), it is also possible to sow earlier. Late sowing delays maturity in the autumn and causes high drying costs. Soybean should not be sown before heavy rain or a prolonged period of rain. Under such conditions, the soil may crust, weeds will hang down, and soybean will rise unevenly, making mechanical weed control very difficult.

Low germination rate and lack of vigour are recurring obstacles in soybean cultivation. Seeds are sensitive to mechanical damage, especially if harvested in too dry or too cold conditions. Cleaning must also be carried out with great care.

The germination capacity can already be considerably reduced during the winter if the seed coat has developed slight cracks during harvesting, cleaning process, transport or storage. Air penetrating the cracks considerably accelerates the ageing of the seed. If in doubt, germination tests should be carried out in early spring. The soak test is also recommended to get a quick first impression of the condition of the seed envelopes, as cracked seeds swell by absorbing water and can practically double in volume (www.Sojaförderring.de).
Soybeans are sown at a row spacing of $30-50 \mathrm{~cm}$ with a pneumatic sowing machine to ensure an even sowing depth and facilitate mechanical weed control with a hoe, ideally with a finger weeder attached. Sowing with a cereal seed drill or weeding only with a harrow is not recommended.

\subsubsection{Weed control}

In rows of $50 \mathrm{~cm}$ distance, the weed control with a mechanical hoe can be accomplished much longer. There are several types of weed management tools /machines on the market, some work in the row, some only between rows and some are row independent. They all have their specific operating time, operating speed and respective adjustments/device settings at different stages of the crop. Bernet et al. (2016) show in the FiBL publication "Biosoja aus Europa" the application of different weeding machines in different stages of organic soybean in a comprehensive diagram (see Fig. 4). This diagram is based on expert interviews with farmers and advisors.

After weeding is complete, about 55 soybean plants per $\mathrm{m}^{2}$ should remain with 00 varieties and around 65 with 000 varieties, because of their reduced branching abilities. With a germination rate of $80 \%$ and mechanical weeding with a fairly aggressive machine setting, resulting plant loss could be up to $1 \%$ per pass. With a target sowing depth of $4 \mathrm{~cm}$, it is possible to carry out a first blind weeding with the weeder harrow, while avoiding driving on the sowing lines and checking that the tines do not damage the seeds in full germination (Bernet et al., 2016, www.bioactualité.ch). 


\subsubsection{Harvest}

Harvest time for soybeans is between Mid September and Mid October. From the beginning of October, the daily sunshine duration decreases noticeably and days with autumn fogs become more frequent. After mid October it is unlikely that the soybeans ripen or dry enough to be harvested at reasonable watercontent between 13 and 16\%. Prior soybean harvest for the food chain big weed plants should be removed to avoid deterioration of quality through staining plant parts in the harvester tank and during stocking and transport. The harvest must, however, be transported as soon as possible to the drying and cleaning facilities of the next mill.

More detailed recommendations for the harvest of soybeans and any other aspect of soybean cultivation can be found on the bioaktuell website, on the Legume Translated Youtube Channel (Videos with subtitle in several European languages) and other sources mentioned in this article.

\section{Conclusion/Outlook}

The cultivation of soybean will play a larger role in the future of organic agriculture in Switzerland. The advances in breeding towards earlier varieties with higher yields $(0000-$ 000 ) and the warmer summers will facilitate this process. The production will have to increase significantly to satisfy only the demand for ruminants. Besides, the saturation of the market for several arable crops will encourage farmers to opt for soybean. On-farm processing does not yet play a role in Switzerland, as most of the farmers sell the harvest to collectors such as Fenaco and Mühle Rytz, however, this may change.

The prospected advances in Swiss soybean breeding for weed suppressive and drought-tolerant varieties will facilitate soybean production in the future for organic as well as for reduced or pesticide-free conventional production systems. Using Swiss bred varieties, $100 \%$ of Swiss value creation in Switzerland from breeding over seed production, processing and feeding or retail can be assured.

New mechanical weed control technologies also contribute to diminish the risk and increase profitability of soybean cultivation. The lower price compensated by a slightly higher yield and less manual labour makes the cultivation of organic feed soybeans economically attractive. Varietal research can also lead to an expansion of the supply by adapting new varieties to conditions that were previously uncommon to this crop. Indeed, the so-called marginal areas, between 500-700 m elevation, could potentially become areas with soil and climate conditions likely to accommodate a large area of soybean production.

To support organic farmers, continuous and updated training and training materials will be made available through various media: field events in cooperation with cantonal extension service and other stakeholders on a local, national and international level like field visits with farmers exchange of experiences, Bioackerbautag 2022 (CH), Oekofeldtage (Germany), organic knowledge platforms liek, bioaktuell.ch (in French and German), publications in FiBL Shop (free download as pdf, various languages), FiBL YouTube channel (www.youtube.com/user/FiBLFilm, see the video about Mechanical weeding machine demonstration as an example:
https://www.youtube.com/watch?v=afYQPAG_Nc) and in online-forms like "farminars", emerging dynamically catalysed by latest events (corona pandemic).

\section{Related projects}

- BLW Soja Projekt: https://www.fibl.org/en/themes/project database/projectitem/project/1600.html

- Bio Speisesoja Schweiz, 2016-2018: www.fibl.org/en/ themes/projectdatabase/projectitem/project/1053.html

- www.diverimpacts.net

- www.legvalue.eu

- www.legumestranslated.eu

\section{References}

Baur P. 2011. Sojaimporte Schweiz: Möglichkeiten und Grenzen der Reduktion/Vermeidung von Sojaimporten in die Schweiz. Eine Untersuchung im Auftrag von Greenpeace, Agrofutura AG. Available from https://www.agrofutura.ch/files/user_upload/ Berichte/2011_Soja_Importe_Schweiz.pdf (Accessed 20/5/2020).

Bernet T, Recknagel J, Asam L, Messmer M. 2016. Biosoja aus Europa, Empfehlungen für den Anbau und den Handel von biologischer Soja in Europa. Available as pdf in FiBL Shop https://shop.fibl.org/chde/1690-biosoja-europa.html.

Bio Suisse 1. 2018. Bio in Zahlen 2018. Available from www.biosuisse.ch/media/Ueberuns/Medien/BioInZahlen/JMK2019/DE/ 7_2018_bio_in_zahlen_de.pdf (Accessed on 5/5/2020).

Bio Suisse 2 . 2020. Teil II Richtlinien für den Pflanzenbau und die Tierhaltung in der Schweiz, Inkraftsetzung Weisungen per 1.1.2020. Available from www.bio-suisse.ch/media/Ueberuns/ Verbandsintern/Inkraftsetz2019/teil_ii_kap_4.2_ftterung_def_d. pdf.

Bio Suisse 3. 2015. Press release. Available from www.bio-suisse.ch/ media/VundH/Import/Downloads/mm_knospe-futter-import nur_noch_aus_europa.pdf (Accessed 20/5/2020).

Bio Suisse 4. 2020. Ricchtlinien für die Erzeugung, Verarbeitung und den Handel von Knospeprodukten, Fassung vom 01. 2020, Chapter II, 2.2.11. Available from https://www.bio-suisse.ch/de/ regelwerkemerkbltter.php (Accessed 20/5/2020).

Dierauer HU, Klaiss M. 2019. Sortenliste Futterbau und übrige Ackerkulturen. FiBL Shop. Available from https://shop.fibl.org/ chde/mwdownloads/download/link/id/183/ (Accessed 20/5/2020).

Döring, TF, Annicchiarco P, Clarke S, et al. 2015. Comparative analysis of performance and stability among composite cross populations, variety mixtures and pure lines of winter wheat in organic and conventional cropping systems. Field Crops Res 183: 235-245.

FiBL Statistics. Available from https://statistics.fibl.org/europe/areaeurope.html?tx_statisticdata_pi $1 \% 5$ Bcontroller\%5D=Element $2 \mathrm{I}$ tem\&cHash $=72 \mathrm{cfbc} 753 \mathrm{cb} 538 \mathrm{a} 4 \mathrm{~b} 246661 \mathrm{c521} \mathrm{cf598}$ (Accessed 20/5/2020).

Hiltbrunner J, Bétrix C-A, Schori A, Clerc M, Messmer M, Messmer R. 2017. Anbaueignung von Sojasorten im Biolandbau in der Schweiz und ihre Eignung für die Tofuherstellung (2013-2015). Agroscope Sci 44: 1-13.

KTBL, Kuratorium für Technik und Bauwesen in der Landwirtschaft (Hrsg). 2015. Faustzahlen für den Ökologischen Landbau. Darmstadt. 
Miersch M. 2017. Anbau von Tofu Sojabohnen, Dem Geheimnis erfolgreichen Vertragsanbaus auf der Spur, Hrsg. Taifun-Tofu $\mathrm{GmbH}, \mathrm{LZ}$ Soja.

Richner W, Sinaj S. 2017. Grundlagen für die Düngung landwirtschaftlicher Kulturen in der Schweiz (GRUD 2017). Agrarforschung Schweiz, Spezialpublikation 8(6): 276S.

Schori A, Charles R, Peter D. 2003. Soja sélection, agronomie et production en Suisse. Revue suisse d'agriculture 35(2): 69-76.

Schwaerzel R, Nussbaum V, Strahm S. 2019. Liste der empfohlenen Sojasorten für die Ernte. Available from www.agroscope.admin. ch/agroscope/de/home/themen/pflanzenbau/ackerbau/kultur arten/soja/soja-sortenliste.html (Accessed 20/5/2020).

Swissgranum. 2019. Übernahmebedingungen Ölsaaten 2020. Available from www.swissgranum.ch/documents/741931/1689161/ 2020-03-18_Uebernahmebedingungen_Oelsaaten_2020_D.pdf/ b54364d8-5e8f-029c-e8ce-3ee5d3f51db7 (Accessed 18/5/2020).

Willer H, Lernoud J. 2019. The World of Organic Agriculture Statistics and Emerging Trends. Research Institute of Organic Agriculture (FiBL) and IFOAM - Organics International.

Zimmer S, Messmer M, Haase T, et al. 2016. Effects of soybean variety and Bradyrhizobium strains on yield, protein content and biological nitrogen fixation under cool growing conditions in Germany. Eur J Agron 72(2016): S38-46.

www.agroscope.admin.ch: https://www.agroscope.admin.ch/agro scope/en/home/topics/plant-production/field-crops/crops/soja/ qualitative-verbesserung.html (Accessed 18/5/2020).

www.bioactualité.ch 1: https://www.bioactualites.ch/cultures/grandescultures-bio/legumineuses-a-graines/soja-bio-recomm.html.

www.bioaktuell.ch: www.bioaktuell.ch/aktuell/agenda/termin/sojazu-tofu-bio-und-regional-vom-anbau-bis-zum-gourmetprodukt. html.

www.bfs.admin.ch: www.bfs.admin.ch/bfs/de/home/statistiken/ raum-umwelt/bodennutzung-bedeckung/bodennutzungswandel. html (Accessed 25/5/2020).

www.fibl.org 1: www.fibl.org/de/themen/projektdatenbank/projekti tem/project/1053.html.

www.fibl.org 2: https://www.fibl.org/de/themen/projektdatenbank/ projektitem/project/1600.html.

www.ige.ch/en/law-and-policy/national-ip-law/indications-ofsource/swiss-indications-of-source/swissness.html (Accessed 18/ 5/2020).

www.sojaförderring.de: www.sojafoerderring.de/anbauratgeber/aus saat/saatgutqualitaet/ (Accessed 12/5/2020).

Cite this article as: Klaiss M, Schmid N, Betrix C-A, Baux A, Charles R, Messmer MM. 2020. Organic soybean production in Switzerland. OCL 27: 64 . 